Submitted $7^{\text {th }}$ August 2019

Accepted $16^{\text {th }}$ November 2019

\title{
TOURISTS EXPECTATION AND PERCEPTION TOWARD SANGEH TOURISM VILLAGE
}

\author{
I Made Bayu Wisnawa ${ }^{1}$, Anak Agung Ratih Wijayanti ${ }^{2}$, Sulistyoadi Jokosaharjo ${ }^{3}$ \\ ${ }^{1}$ Sekolah Tinggi Pariwisata Triatma Jaya, Indonesia \\ bayu.wisnawa@triatma-mapindo.ac.id_ratih.wijayanti@triatma-mapindo.ac.id , \\ sulistyoadi.saharjo@triatma-mapindo.ac.id
}

\begin{abstract}
Sangeh is a tourism village which has tourism potentials such as nature scenery, rice field, forest, and culinary. This research studies the expectation and perception of the tourists who visit Sangeh. A qualitative method using questionnaire and interview techniques was used in the research. There were 155 respondents in which the questionnaire was distributed offline and online. This research aims to find out the expectation, perception, and satisfaction of the tourists in enjoying their tourism visit in Sangeh, and also to find out the efforts which can be done by the management in increasing tourists' satisfaction in enjoying the tourism visit. The results show that the tourists' expectation is on the installation of road signs which enable them to reach Sangeh easily. The highest perception felt by the tourists is its beautiful natural scenery. The biggest gap felt by the tourists is the internet connection. The effort which should be done by the management is by providing additional supporting facilities.
\end{abstract}

Keywords: Expectation, Perception, Tourists, Tourism Village

\section{INTRODUCTION}

Tourism experiences remarkable growth in the last five years (Pantiyasa, 2019). Tourism is the main economic driver in various countries in the world (Brunner, 2010). The development of tourism will be able to speed up the development and prosperity of the society. The development of tourism should be based on the involvement of local society. By the involvement of local society, therefore, the cultural, economic, and environmental aspects will be able to be maintained as forms of sustainable tourism development (Putra, 2016).

Bali is a small island, in which, its main source of development comes from tourism. Bali tourism has a great contribution in the national tourism development. Other than the contributions from foreign exchange and tax, Bali philosophy of Tri Hita Karana also inspires national tourism development in developing the ten tourism destinations of 'New Bali' or 'Bali Baru' (CNN Indonesia, 2018) which cover: (i) Danau Toba, (ii) Tanjung Kelayang, (iii) Tanjung Lesung, (iv) Pulau Seribu, (v) Candi Borobudur, (vi) Mandalika, (vii) Gunung Bromo, (viii) Wakatobi, (ix) Labuan Bajo, and (x) Morotai.

Sangeh is a village located in Abian Semal District, Badung Regency. It becomes a tourism village officially by the Regulation of Badung Regent No.47 
Year 2010 (Astara, 2018). There are many advancements achieved by the development of tourism potentials of this village (Putra, 2015; Arsawan, et al, 2016). To 2019, based on the accessibility of all main roads are smooth and made of asphalt, and the alleys are paved. There are many tourism attractions, other than Sangeh Monkey Forest, such as Penglukatan Pancoran Solas Taman Mumbul which is still in development. Other tourism attractions are starting to develop such as nature scenery of rice field, forest, and culinary. The amenities are also growing. There is Pondok Jaka Sangeh which provides a place for gathering, team building, culinary, tracking, and cycling. The same goes for the accommodation by the growth of villas, such as Villa Cafein. The management of Sangeh Tourism Village cannot be separated from the role of Desa Adat or Custom Village (Atmadja, 2016; Astara, 2018; Sukadana and Raka, 2002). The example of the role of desa adat is applying Bali local genius: Tri Hita Karana (Parahyangan, Pawongan, Palemahan). It can be stated that the local society of Sangeh Village has felt the result of tourism development by the role of desa adat. As a form of a good tourism village management, the role of desa adat is supported by Pokdarwis Desa Wisata Sangeh (the Tourism-Aware Group of Sangeh Tourism Village) as the management of two tourism objects: Sangeh Monkey Forest and Penglukatan Pancoran Solas Taman Mumbul.

Tourist is a stakeholder who holds an important role in a tourism destination. Without tourist, a tourism destination will not exist. Therefore, the satisfaction of the tourists in enjoying their tourism visit in a destination is an absolute consideration for the management.

\section{Figure 1}

Tourists Comment and Assessment Toward Sangeh Tourism Village
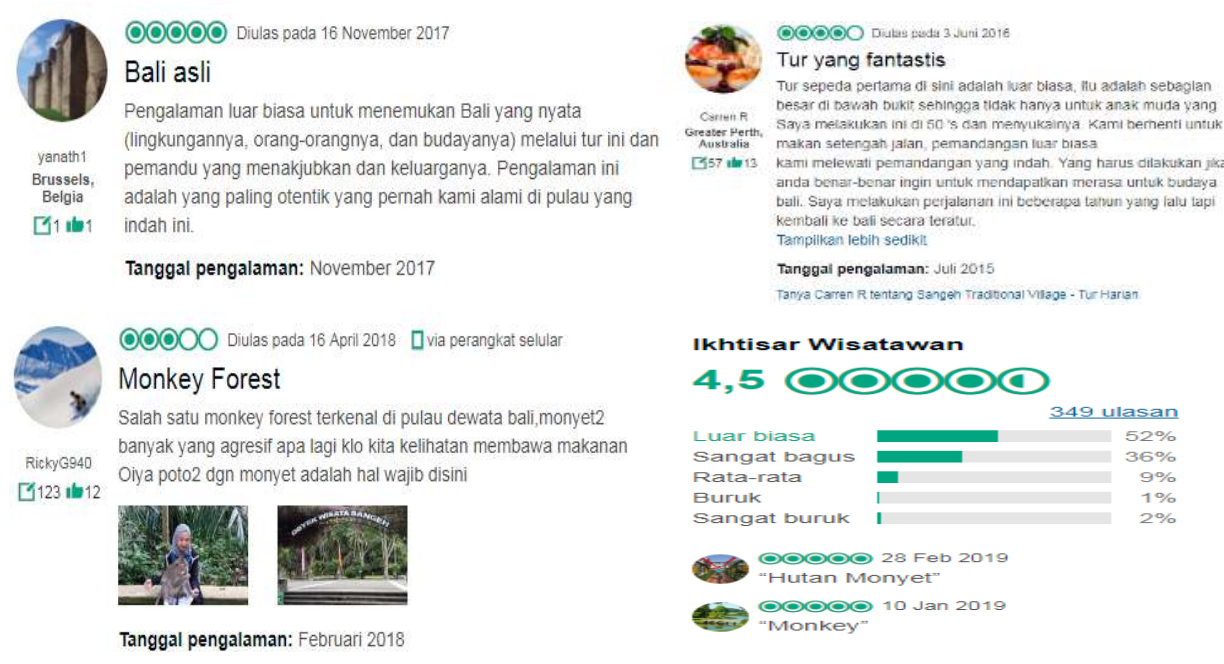

Source: www.tripadvisor.co.id.,2019 accessed on May 19 th 2019

Based on Figure 1, it can be seen that from 349 tourist reviews, $88 \%$ of the reviews consider Sangeh tourism destination as Marvelous and Very Good, while those who considers it as common, bad, and worse is only $12 \%$. 


\section{Figure 2}

\section{Sangeh Tourism Village Rank Based on Google Trends (2014 to 2019)}

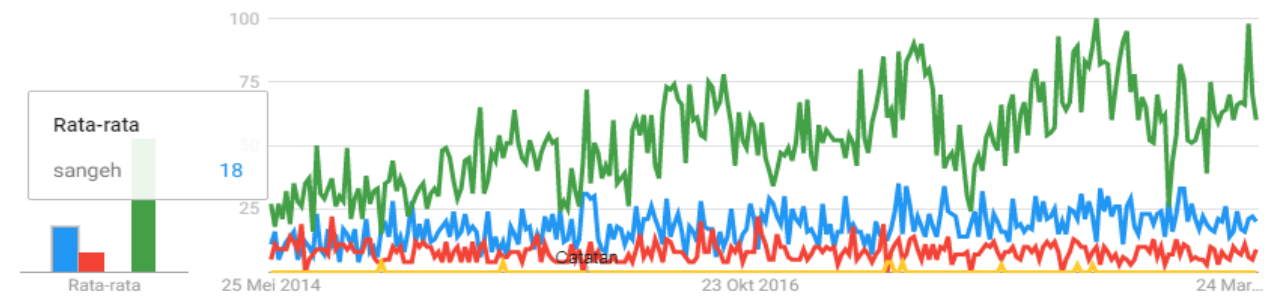

Source: www.trends.google.com,2019 accessed on May 19 ${ }^{\text {th }}, 2019$

Figure 2 shows Sangeh popularity toward its closest competitors in the last five years: (i) Ubud Monkey Forest, (ii) Alas Kedaton, and (iii) Kiadan. The popularity rank of Sangeh is on the $2^{\text {nd }}$ rank (18 per day), while Ubud is on the $1^{\text {st }}$ rank (53 per day), Alas Kedaton on the $3^{\text {rd }}$ rank ( 8 per day), while Kiadan is in the $4^{\text {th }}$ rank (n/a). Sangeh popularity trend tends to be flat if it is compared to the trend of Ubud Monkey Forest which tends to rise.

Even though Sangeh Tourism Village has experienced a vast development due to the hard work of tourism village management, the evaluation related to tourists' satisfaction should still be conducted continuously for planning, organizing, directing, and controlling. In other words, the management function in the tourism village management should be sustainable.

\section{Problem Formulation}

1. What is the expectation of the tourists in enjoying their tourism visit in Sangeh Tourism Village?

2. What is the perception of the tourists in enjoying their tourism visit in Sangeh Tourism Village?

3. How satisfy are of the tourists in enjoying their tourism visit in Sangeh Tourism Village?

4. What kind of efforts which should be done by the management in increasing the satisfaction of the tourists in enjoying their tourism visit in Sangeh Tourism Village?

\section{Research Aims}

1. To find out the expectation of the tourists in enjoying their tourism visit in Sangeh Tourism Village.

2. To find out the perception of the tourists in enjoying their tourism visit in Sangeh Tourism Village.

3. To find out the satisfaction of the tourists in enjoying their tourism visit in Sangeh Tourism Village.

4. To find out the efforts which should be done by the management in increasing the satisfaction of the tourists in enjoying their tourism visit in Sangeh Tourism Village.

\section{Significance of the Research}

Theoretically, this research is expected to give merits in developing tourism science especially in marketing and tourists behaviors sectors. Empirically, this 
research is expected to give merits in giving inputs and suggestions in increasing the management of Sangeh Tourism Village.

\section{THEORETICAL REVIEW}

Nowadays, researches related to tourism are growing. It shows that the existence of tourism science, from axiology and entomology aspects as a unity, will continue to develop in accordance with the tourism growth in the world especially in Indonesia. Oviedo-Garcia (2016) state that tourism research has inter-disciples characteristics which involve many institutions, actors, and network in a framework of social science (Tribe, 2004, 2010). In synergizing those knowledges, there are often gaps met which have functions of producing new concepts, methods, and knowledges. Tourism research studies the object on the activity of human experiences for fun, starting from planning, choosing travel package and destination, taking decision, enjoying the visit, until going back home. From axiology aspect, tourism as a science has merits in giving solutions for the problems faced by tourism practitioners which cover government, society, businessman, tourist, academician, and mass media.

There are many researches on Sangeh Village. Those researches are multidimensional and inter-dimensional. Atmadja (2016) conducts a research on monkey forest tourism area in Sangeh Village, Bali. He studies the role of desa adat in managing the tourism objects. Astara (2018) conducts a study on the law of public management of tourism village in Bali. Parma (2013) conducts a study on the sustainable tourism development based on the perspective of spatial perspective in Bali. Sukadana (2002) conducts a study in the role of desa adat in preserving the environmental function. Arsawan (2016) conducts a study to formulate a revitalization strategy for Sangeh tourism area. Those researches use multidisciples approaches such as cultural, law, environmental, and managerial approaches.

Kusherdyana (2011) and Kotler (1993) define perception as how a person selects, rules, and interprets input of information to create a whole meaningful description. Expectation or hope is a condition felt by the tourists toward the fulfilment of needs and desires in doing a tourism visit based on the sacrifice which has been done (Han, Lee, \& Hwang, 2016). Tourist satisfaction is the fulfilment of all of the hope and expectation with the reality during and after doing a tourism visit (Oviedo Garcia, et.al., 2019). Tourists experience involves all senses, influences cognitive and affective aspects which determines the tourists' satisfaction level and taking decision (Bartella, 2016)

Tourism attribute is an important dimensions collection which should be present and becomes a factor which creates tourists' comfort in enjoying a tourism destination, and it becomes a point which will be assessed by the tourists in their visit experience (Smith and Deppa, 2009). There are many experts who describe attributes which should be present in a tourism destination (Abdullah, 2017). Chahal and Devi (2015) propose 5A Concept; Attractions, Accommodation, Accessibility, Awareness and Ancillaries Services. Buhalis (2000) uses 6A Concept (Attractions, Amenities, Accessibility, Activities, Available Packages dan Ancillaries Services). Holloway, Humphreys and Davidson (2005) propose 3A Concept (Attractions, Amenities and Accessibility). This research uses tourism destination attributes concept as proposed by Medlik (1980) in Ariyanto and 
Cooper, et.al. (1993) which uses 4A Concept; Attractions, Accessibilities, Amenities, Ancillaries, with the addition of Community Involvement as proposed by Madiun (2010).

\section{Figure 3}

\section{Conceptual Framework}

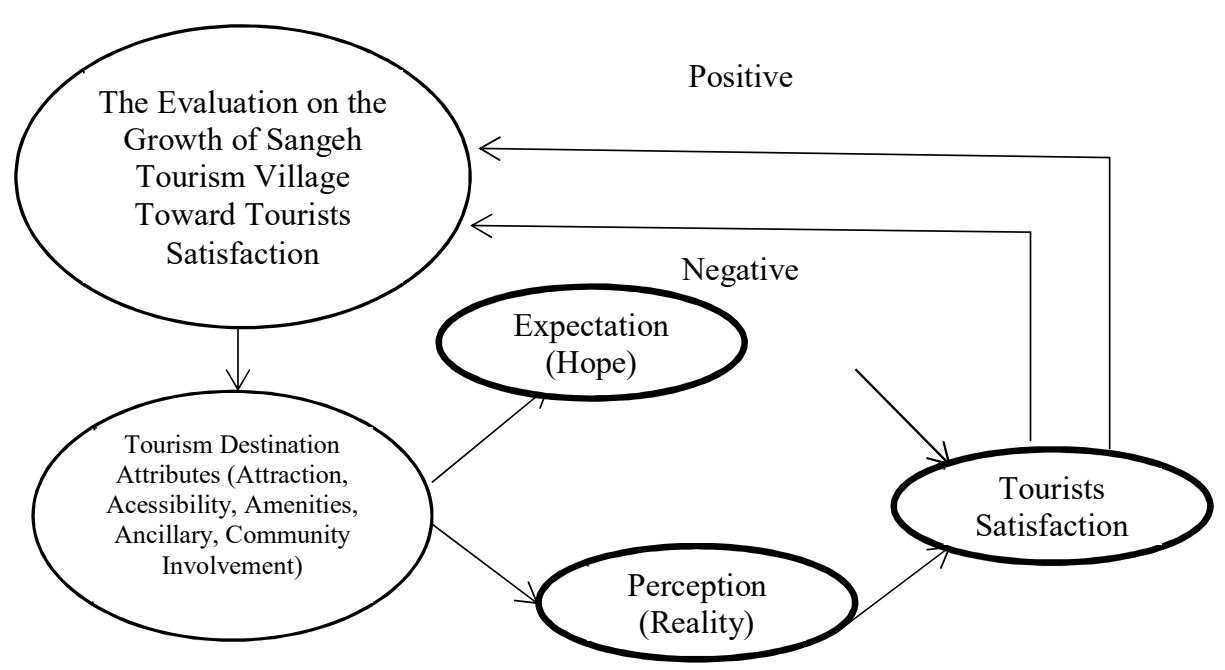

\section{METHODOLOGY}

This research uses a qualitative method by using instruments of (i) questionnaire to measure tourist perception, (ii) interview items to obtain deeper understanding on the descriptive statistical finding. There were 155 respondents used in the research. The questionnaire was distributed online and offline. The questionnaire was tested using validity and reliability tests before it was distributed. There were two data used in the research; (i) qualitative data in form of tourists' opinion on Sangeh, location, and the history of Sangeh, and (ii) quantitative data in form of Sangeh popularity rank and result from questionnaire tabulation. The data were obtained through observation, survey, documentation, and interview methods.

\section{RESULTS AND DISCUSSION}

\section{Tourists Expectation in Enjoying Their Tourism Visit in Sangeh Tourism Village.}

The expectation of the tourists in enjoying their tourism visit in Sangeh Tourism Village can be seen on the Table 1 below. 
Table 1

Tourists Expectation Toward Sangeh Tourism Village

\begin{tabular}{|l|l|c|c|}
\hline No & \multicolumn{1}{|c|}{ Indicators } & Variables & Mean Score \\
\hline 1. & ROAD SIGN makes it EASIER to reach the location & Amenity & 4.6129 \\
\hline 2. & TOILETS are available & Amenity & 4.5935 \\
\hline 3. & Sangeh Tourism Village is PROPERLY managed & Ancillary & 4.5742 \\
\hline 4. & The road in Sangeh Tourism Village is GOOD & Access & 4.5677 \\
\hline 5. & $\begin{array}{l}\text { Sangeh Tourism Village is managed by TOURISM - } \\
\text { AWARE GROUP (POKDARWIS) }\end{array}$ & Ancillary & 4.5677 \\
\hline 6. & $\begin{array}{l}\text { Internet connection in Sangeh Tourism Village is } \\
\text { STABLE }\end{array}$ & Access & 4.5613 \\
\hline 7. & $\begin{array}{l}\text { THE SCENERY in Sangeh Tourism Village is } \\
\text { BEAUTIFUL }\end{array}$ & Attraction & 4.5613 \\
\hline 8. & Eat and drink facilities are available & Amenity & 4.5548 \\
\hline 9. & $\begin{array}{l}\text { Monkey Forest tourism object in Sangeh Tourism } \\
\text { Village is INTERESTING }\end{array}$ & Attraction & 4.5484 \\
\hline 10. & No difficulty in PARKING & Amenity & 4.5484 \\
\hline 11. & $\begin{array}{l}\text { The culinary in Sangeh Tourism Village is } \\
\text { DELICIOUS Attraction }\end{array}$ & 4.5419 \\
\hline 12. & $\begin{array}{l}\text { Taman Mumbul tourism object in Sangeh Tourism } \\
\text { Village is INTERESTING }\end{array}$ & Attraction & 4.5032 \\
\hline 13. & $\begin{array}{l}\text { THE LOCAL GUIDES are able to answer all of your } \\
\text { questions }\end{array}$ & Amenity & 4.5032 \\
\hline 14. & $\begin{array}{l}\text { The information about Sangeh Tourism Village is } \\
\text { EASY to obtain }\end{array}$ & Access & 4.4581 \\
\hline 15. & Easy to find souvenir shops & Amenity & 4.3226 \\
\hline & $\mathbf{4 . 5 3 6 6}$ \\
\hline
\end{tabular}

Based on Table 1, the highest score of tourists' expectation is the amenity variable on the indicator of road sign which makes it easier to reach the location. Most of the tourists expect to find road signs which will help them to reach the tourism destination in Sangeh Tourism Village. The lowest score of tourists' expectation is the amenity variable on the indicator of easy to find souvenir shops. It means that compared to other indicators, the tourists who visit Sangeh Tourism Village do not have a high expectation to find shops which sell special souvenir of Sangeh Tourism Village.

\section{Tourists Perception in Enjoying Their Tourism Visit in Sangeh Tourism Village.}

Tourists perception in enjoying their tourism visit in Sangeh Tourism Village can be seen on the Table 2 below. 
Table 2

\begin{tabular}{|l|l|c|c|}
\multicolumn{4}{|c|}{ Reality Obtained by The Tourists on Sangeh Tourism Village } \\
\hline No & \multicolumn{1}{|c|}{ Indicators } & Variables & Means \\
\hline 1. & $\begin{array}{l}\text { THE SCENERY in Sangeh Tourism Village is } \\
\text { BEAUTIFUL }\end{array}$ & Attraction & 4.3742 \\
\hline 2. & $\begin{array}{l}\text { Culinary in Sangeh Tourism Village is } \\
\text { DELICIOUS }\end{array}$ & Attraction & 4.3419 \\
\hline 3. & $\begin{array}{l}\text { Taman Mumbul tourism object in Sangeh } \\
\text { Tourism Village is INTERESTING }\end{array}$ & Attraction & 4.2774 \\
\hline 4. & No difficulty in PARKING & Amenity & 4.2645 \\
\hline 5. & $\begin{array}{l}\text { The information about Sangeh Tourism Village is } \\
\text { EASY to obtain }\end{array}$ & Access & 4.2581 \\
\hline 6. & Eat and drink facilities are available & Amenity & 4.2194 \\
\hline 7. & $\begin{array}{l}\text { ROAD SIGN makes it EASIER to reach the } \\
\text { location }\end{array}$ & Amenity & 4.1677 \\
\hline 8. & $\begin{array}{l}\text { Monkey Forest tourism object in Sangeh Tourism } \\
\text { Village is INTERESTING }\end{array}$ & Attraction & 4.1677 \\
\hline 9. & TOILETS are available & Amenity & 4.0452 \\
\hline 10. & Sangeh Tourism Village is PROPERLY managed & Ancillary & 4.0258 \\
\hline 11. & Easy to find souvenir shops & Amenity & 3.9548 \\
\hline 12. & The road in Sangeh Tourism Village is GOOD & Access & 3.9484 \\
\hline 13. & $\begin{array}{l}\text { Sangeh Tourism Village is managed by } \\
\text { TOURISM - AWARE GROUP }(P O K D A R W I S)\end{array}$ & Ancillary & 3.9355 \\
\hline 14. & $\begin{array}{l}\text { THE LOCAL GUIDES are able to answer all of } \\
\text { your questions }\end{array}$ & Amenity & 3.8903 \\
\hline 15. & $\begin{array}{l}\text { Internet connection in Sangeh Tourism Village is } \\
\text { STABLE }\end{array}$ & Access & 3.5548 \\
\hline & \multicolumn{1}{|c|}{ Mean Score } & 4.1198 \\
\hline
\end{tabular}

Based on the Table 2, the highest score of tourists' perception in reality is the attraction variable on the indicator of the nature scenery in Sangeh Tourism Village which becomes a tourism potential and should be maintained and preserved. The lowest score of tourists' perception in reality is the access variable on the indicator of internet connection in Sangeh Tourism Village. The tourists who visit Sangeh Tourism Village consider the internet as still unstable.

\section{Tourists Satisfaction in Enjoying Their Tourism Visit in Sangeh Tourism} Village.

The satisfaction of the tourists in enjoying their tourism visit in Sangeh Tourism Village can be seen in the Table 3 below.

Table 3

\section{Reality Obtained by the Tourists Toward Sangeh Tourism Village}

\begin{tabular}{|l|l|c|c|c|}
\hline No & \multicolumn{1}{|c|}{ Indicators } & Expectation & Reality & Difference \\
\hline 1. & $\begin{array}{l}\text { Internet connection in Sangeh Tourism } \\
\text { Village is STABLE (Access) }\end{array}$ & 4.5613 & 3.5548 & $(1.0065)$ \\
\hline
\end{tabular}




\begin{tabular}{|c|c|c|c|c|}
\hline 2. & $\begin{array}{l}\text { THE LOCAL GUIDES are able to answer } \\
\text { all of your questions (Amenity) }\end{array}$ & 4.5325 & 3.8903 & $(0.6421)$ \\
\hline 3. & $\begin{array}{l}\text { The road in Sangeh Tourism Village is } \\
\text { GOOD (Access) }\end{array}$ & 4.5677 & 3.9484 & $(0.6194)$ \\
\hline 4. & $\begin{array}{l}\text { Sangeh Tourism Village is managed by } \\
\text { TOURISM - AWARE GROUP } \\
(P O K D A R W I S) \text { ((Ancillary) }\end{array}$ & 4.5677 & 3.9610 & $(0.6067)$ \\
\hline 5. & TOILETS are available (Amenity) & 4.5935 & 4.0452 & $(0.5484)$ \\
\hline 6. & $\begin{array}{l}\text { Sangeh Tourism Village is PROPERLY } \\
\text { managed (Ancillary) }\end{array}$ & 4.5742 & 4.0519 & $(0.5222)$ \\
\hline 7. & $\begin{array}{l}\text { ROAD SIGN makes it EASIER to reach } \\
\text { the location (Amenity) }\end{array}$ & 4.6129 & 4.1677 & $(0.4452)$ \\
\hline 8. & $\begin{array}{l}\text { Monkey Forest tourism object in Sangeh } \\
\text { Tourism Village is INTERESTING } \\
\text { (Attraction) }\end{array}$ & 4.5484 & 4.1677 & $(0.3806)$ \\
\hline 9. & Easy to find souvenir shops (Amenity) & 4.3226 & 3.9548 & $(0.3677)$ \\
\hline 10. & $\begin{array}{l}\text { Eat and drink facilities are available } \\
\text { (Amenity) }\end{array}$ & 4.5548 & 4.2468 & $(0.3081)$ \\
\hline 11. & No difficulty in PARKING (Amenity) & 4.5484 & 4.2645 & $(0.2839)$ \\
\hline 12. & $\begin{array}{l}\text { Culinary in Sangeh Tourism Village is } \\
\text { DELICIOUS (Attraction) }\end{array}$ & 4.5419 & 4.3419 & $(0.2000)$ \\
\hline 13. & $\begin{array}{l}\text { THE SCENERY in Sangeh Tourism } \\
\text { Village is BEAUTIFUL (Attraction) }\end{array}$ & 4.5613 & 4.3742 & $(0.1871)$ \\
\hline 14. & $\begin{array}{l}\text { The information about Sangeh tourism } \\
\text { village is EASY to obtain including via } \\
\text { online (Access) }\end{array}$ & 4.4581 & 4.2857 & $(0.1724)$ \\
\hline 15. & $\begin{array}{l}\text { Taman Mumbul tourism object in Sangeh } \\
\text { Tourism Village is INTERESTING }\end{array}$ & 4.5032 & 4.5419 & 0.0387 \\
\hline & Mean Score & 4.5366 & 4.1198 & $(0.4168)$ \\
\hline
\end{tabular}

Table 3 shows the comparison of expectation and perception of the tourists who visit Sangeh Tourism Village. The highest gap is on the access variable on the indicator of internet connection in Sangeh Tourism Village. On the amenity variable, the highest gap is on the indicator of local guides are able to answer all of the tourists' questions. Not every tourism object in Sangeh Tourism Village provides local guides who are able to answer all of the tourists' questions. The example can be seen in Sangeh Monkey Forest. The available local guides can be located in each post; however, they do not always provide information to tourists but more into keeping out the monkeys so that they will not hurt the tourists. In addition, usually the tourists have their own guide, therefore, the local guides are always able to communicate with the tourists.

On ancillary variable, the highest gap is on the indicator of Sangeh Tourism Village is managed by tourism-aware group (POKDARWIS). On the attraction variable, the highest gap is on the indicator of Monkey Forest tourism object in Sangeh Tourism Village is interesting. It might be caused by the present of similar tourism objects such as Ubud Monkey Forest. The lowest gap between the expectation and the perception of the tourists in Sangeh Tourism Village is 
on the attraction variable on the indicator of Taman Mumbul tourism object in Sangeh Tourism Village is interesting. It means that the expectation and perception of the tourists who visit Taman Mumbul tourism object in Sangeh Tourism Village is almost the same.

\section{Efforts Should be Done by the Management in Increasing the Satisfaction of the Tourists in Enjoying Their Tourism Visit in Sangeh Tourism Village.}

The effort which will be done by the management in increasing the satisfaction of the tourists should consider the tourism destination variables. For instance, providing free Wi-Fi area in the Sangeh tourism object. It can become a supporting facility which is useful in adding the advantage of Sangeh tourism objects. In addition, the number of the local guides should be increased and they should be trained periodically. The training for the local guides can be in form of foreign languages, tourism objects knowledge, and tourism service quality trainings. By the present of those trainings, it is expected to be able to increase visitors to Sangeh Tourism Village. Other than giving training toward local guides, the management can increase and maintain the available facilities of the tourism village. The increase of facility can be in form of providing clean and comfortable toilets for the tourists, installing road signs which will enable the tourists to easily reach Sangeh Tourism Village.

\section{CONCLUSION AND SUGGESTION}

The highest hope or expectation of the tourists who visit Sangeh Tourism Village is on the installation of road signs which enable tourists to reach the tourism destinations in Sangeh Tourism Village. On the reality or tourists' perception, they consider Sangeh as a tourism village which has a beautiful natural scenery. The gap between the expectation and the reality which is faced by the tourists is the unstable internet connection and the local guides which are expected to be able to answer all of the tourists' questions related to tourism objects in Sangeh Tourism Village. Based on the findings, it can be concluded that the gap between the tourists' expectation and the reality which can be found in Sangeh Tourism Village is not to big because tourists' expectation is almost similar to the reality which tourists can get in Sangeh Tourism Village.

In order to increase and develop Sangeh Tourism Village, it requires cooperation of all stakeholders such as government, village head, TourismAware Group (POKDARWIS), and the tourism object managements. The available supporting facilities in Sangeh Tourism Village should be increased and maintained by everyone. Moreover, it requires service quality increase in order to increase number of tourists who will visit Sangeh Tourism Village.

\section{REFERENCES}

Abdullah, Taufik. (2017). Penilaian Wisatawan akan Atribut Pariwisata di Kota Batu. Tourism and Hospitality Essentials (THE) Journal, Vol. 7, No. 2, 2017.pp.91-96.

Ariyanto. (2005). Ekonomi Pariwisata.Jakarta:Rhineka Cipta 
Atmadja, Nengah Bawa. (2016). Pelestarian Kawasan Hutan Wisata Kera di Desa Sangeh, Bali : Suatu Telaah Tentang Peranan Desa Adat Dalam Mengelola Obyek Wisata. Tesis. Jakarta : Universitas Indonesia. http://lib.ui.ac.id/opac/ui/detail.jsp?id=81745\&lokasi=lokal

Brunner, Edward. (2010). New Paradigm of Tourism Review of The Literature from 2005 to 2009, Scientific Research in Tourism.

Buhalis, Dimitrios. (2000). "Marketing the competitive destination of the future", Tourism Management, 21 (1), 97-116

Cooper, Chris. Dkk. (1993). Tourism Principles \& Practice. England: Longman Group.

Holloway, J. Christopher, Humphreys , Claire, dan Davidson, Rob. (2009). The Business of Tourism, 8th Edition. England: Pearson Education Limited

Kusherdyana, (2011). Pemahaman Lintas Budaya dalam Konteks Pariwisata dan Hospitality. Bandung : Alfabeta

Madiun, I Nyoman. (2010). Nusa Dua: Model Pengembangan Kawasan Wisata Modern. Denpasar. Udayana University Press

Oviedo-García, M. Á. (2016). Tourism research quality: Reviewing and assessing interdisciplinarity. Tourism Management, 52, 586592.doi:10.1016/j.tourman.2015.08.011

Oviedo-García, M. Á., Vega-Vázquez, M., Castellanos-Verdugo, M., \& OrgazAgüera, F. (2019). Tourism in protected areas and the impact of servicescape on tourist satisfaction, key in sustainability. Journal of Destination Marketing \& Management, 12, 74-83. doi:10.1016/j.jdmm.2019.02.005 .

Pantiyasa, I Wayan. (2019). Konstruksi Model Pengembangan Desa Wisata menuju Smart Eco-Tourism di Desa Paksebali, Klungkung, Bali. Jurnal Kajian Bali Vol.9 No.1. Denpasar : Pusat Kajian Bali dan Pusat Unggulan Pariwisata Universitas Udayana.

Park, S., Hahn, S., Lee, T., \& Jun, M. (2018). Two factor model of consumer satisfaction: International tourism research. Tourism Management, 67, 82-88.doi:10.1016/j.tourman.2018.01.007

Putra, I Nyoman Darma (ed.). (2016). Pariwisata Berbasis Masyarakat Model Bali. Denpasar : Prasasti.

Smith, R., \& Deppa, B. (2009). Two dimensions of attribute importance. Journal of Consumer Marketing, 26(1), 28-38. https://doi.org/10.1108/07363760910927028

Tribe, J. (2004). Knowing about tourism. Epistemological issues. In J. Phillimore, \& L. Goodson (Eds.), Qualitative research in tourism: Ontologies, epistemologies and methodologies (pp. 46e62). London: Routledge.

Tribe, J. (2010). Tribes, territories and networks in the tourism academy. Annals of Tourism Research, 37(1), 7e33. 